\title{
COVID-19: Has social isolation reduced the emission of pollutants in the megacity of São Paulo-Brazil?
}

\author{
Lumy Noda $^{1}$ (D) . Ana Beatriz E. Q. Nóbrega ${ }^{1}$ (D) João B. M. da Silva Júnior ${ }^{1}$ (D) \\ Flávio Schmidlin ${ }^{1}$ (D) . Lucila Labaki ${ }^{1,2}$ (D)
}

Received: 24 August 2020 / Accepted: 15 December 2020 / Published online: 3 January 2021

(c) The Author(s), under exclusive licence to Springer Nature B.V. part of Springer Nature 2021

\begin{abstract}
The first case of COVID-19 in Brazil was registered in the city of São Paulo on February 26, 2020; however, restrictive measures and social distancing were only determined in the city on March 17, 2020. A partial lockdown aimed to mitigate the advance of the virus by raising the social isolation rates, by limiting the operation of several services and the mobility of the population. Thus, this study aims to analyze the relationship between the social isolation index in the city of São Paulo and the emission levels of the main air pollutants $\left(\mathrm{PM}_{10}, \mathrm{PM}_{2.5}, \mathrm{NO}_{\mathrm{x}}, \mathrm{NO}, \mathrm{NO}_{2}, \mathrm{SO}_{2}\right.$ and $\left.\mathrm{CO}\right)$, as well as air temperature. We analyzed the data collected from three urban air quality monitoring stations located in the city center of São Paulo from March 16, 2020 to July 20, 2020. The data for 2020 were compared with those of the previous period in 2020 and the same period in the previous 5 years (2015-2019), and also to the city's official indices of social isolation. The relationships between pollutant concentrations and the social isolation index showed that the decrease in mobility influenced the reduction in air pollution. Pollutants $\mathrm{NO}_{2}, \mathrm{NO}_{\mathrm{x}}, \mathrm{NO}$ and $\mathrm{CO}$ had the strongest negative associations (Pearson's correlation $=-0.582 ; 0.481 ;-0.433$ and -0.367 , respectively). Our results showed that the partial lockdown (from March 17, 2020, to July 20,2020 ) had a positive impact on air quality, with a reduction in the emission of pollutants $\mathrm{NO}(31.75 \%), \mathrm{NO}_{2}(20.60 \%), \mathrm{NO}_{\mathrm{x}}(27.21 \%)$ and $\mathrm{CO}(29.95 \%)$. The greatest reductions in the emission of pollutants were observed when the social isolation index reached an average of $52.20 \%$. Small negative fluctuations in the social isolation index broke the most significant reductions observed at the beginning of social isolation.
\end{abstract}

Lumy Noda

barbara.lumy@academico.ufpb.br

1 Postgraduate Program of Architecture and Urbanism, Federal University of Paraíba, Campus I Lot. Cidade Universitária, CEP 58051-900 João Pessoa, Paraíba, Brazil

2 Department of Architecture and Construction, State University of Campinas, Cidade Universitária Zeferino Vaz, CEP 13084-971 Campinas, São Paulo, Brazil 


\section{Graphic abstract}

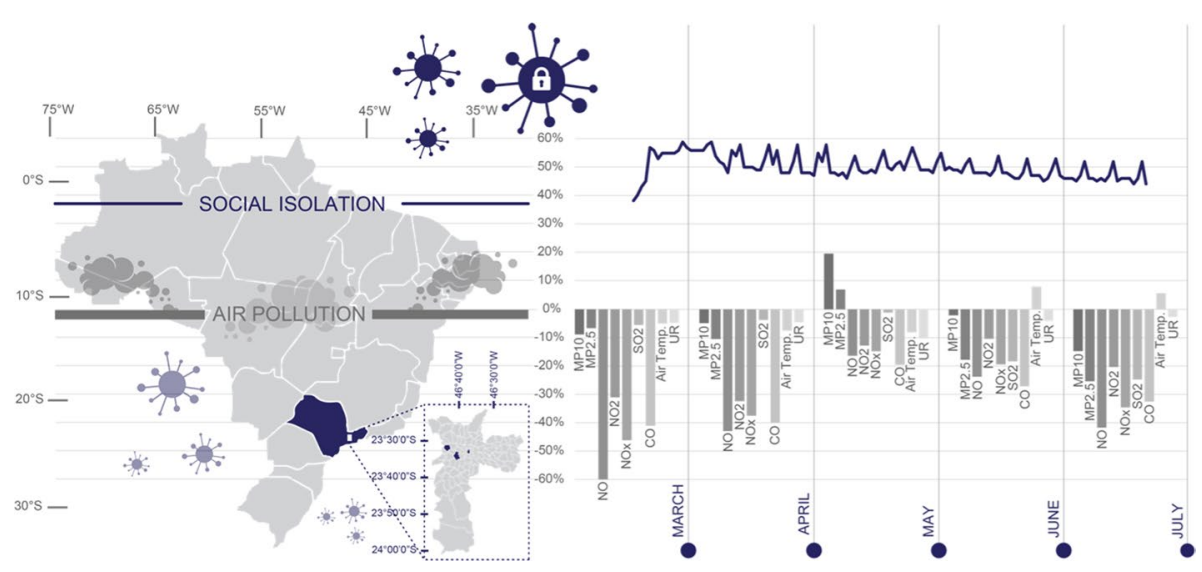

Keywords Air quality · Atmospheric pollution · Quarantine · Partial lockdown · Urban mobility

\section{Introduction}

In December 2019, the world found itself living with an unknown type of highly contagious biological agent that caused severe respiratory symptoms. The first case of the disease caused by SARS-CoV-2 was reported in the Chinese province of Wuhan and quickly spread across the globe to reach the status of pandemic (Layne et al. 2020; Yang et al. 2020; Shehzad et al. 2020). COVID-19 spread so quickly in 2020 that it required worldwide emergency measures of social distancing and quarantine in almost all major cities around the world as a way to reduce contagion (Rodríguez-Urrego and Rodríguez-Urrego 2020; Bera et al. 2020). Closing schools and restaurants, urging people to stay at home and reduce physical contact and interactions still are the most effective form of prevention (Guo et al. 2020; Tian et al. 2020; Wilder-Smith and Freedman 2020). In Wuhan, the first isolation measures adopted were to ban travel, limit traffic, suspend transport and close factories, which had a substantial effect and reduced the spread of the virus (Bao and Zhang 2020).

The pandemic, a challenge in terms of global health, has shed light, in quantitative terms, on the impact of the emission of pollutants generated by human activity in the cities, in a context of reduced urban mobility never before seen in the twenty-first century. Muhammad et al. (2020) state that transport is the sector affected the most by the lockdown; based on Google's Mobility Index Report, those researchers identified reductions in the transport sector between February 23rd and April 5th, 2020, in Spain (89\%), Italy (86\%), France (82\%), England (70\%), Germany (47\%) and the USA (54\%), and there is a consensus that anthropogenic emission reductions, mainly in transportation and the industry, contributed to a decrease in air pollutant concentrations (Wang et al. 2020). In this context, several studies identified various levels of pollutant reduction in the main cities that have adopted urban mobility constraints as a strategy to mitigate COVID-19 contamination. 
Initially, by combining satellite observations with detailed computer models of the atmosphere, studies released at the beginning of the pandemic indicated a reduction of about $20-30 \%$ in particulate matter (PM) on the surface of much of China. Part of the reduction in the concentration of nitrogen dioxide $\left(\mathrm{NO}_{2}\right)$ in the troposphere was attributed to the impact of the Coronavirus, with a reduction of about $40 \%$ in Chinese cities (EESA 2020a). Satellite images also demonstrate a significant reduction in average $\mathrm{NO}_{2}$ concentrations in major cities in India, with a pollutant decrease of about 40-50\% in Mumbai and Delhi (India) compared with the same period in 2019 (EESA 2020b). In Italy and France, $\mathrm{NO}_{2}$ levels decreased between 45 and 50\% compared with the same period in 2019. Madrid (Spain), Milan and Rome (Italy) had drops of around 45\% while Paris (France) had a dramatic reduction of about 54\%, coinciding with the strict quarantine measures implemented across Europe (EESA 2020c).

Confirming findings from satellite images, local studies assessed the impacts of lockdown on air quality and pollutant emissions of anthropogenic origin using data from local monitoring stations. The first city to adopt the lockdown, Wuhan (China) had strong reductions in PM concentration $(\sim 42 \%)$, in nitrogen oxides $\left(\mathrm{NO}_{\mathrm{x}}\right)$ rates $(\sim 56 \%)$, and average $\mathrm{NO}_{2}$ concentrations $(\sim 57 \%)$, when comparing the isolation period with the same period in the years 2017-2019 (Sicard et al. 2020). Data from urban stations in Delhi (India), one of the cities with the highest pollution indices in the world, showed that during the lockdown there was a significant improvement in air quality, especially when comparing the concentrations of particulate matter with an aerodynamic diameter under $2.5 \mu \mathrm{m}\left(\mathrm{PM}_{2.5}\right)$ and $10 \mu \mathrm{m}\left(\mathrm{PM}_{10}\right)$, whose maximum reduction reached $50 \%$ when compared with a period prior to the lockdown. $\mathrm{NO}_{2}$ concentrations and carbon monoxide (CO) emissions also decreased by $52.68 \%$ and $30.35 \%$, respectively (Mahato et al. 2020). Kolkata (India) had a reduction in the $\mathrm{PM}_{10}$ and $\mathrm{PM}_{2.5}$ concentration around $17.5 \%$, while the pollutants $\mathrm{CO}$, $\mathrm{NO}_{2}$ and sulfur dioxide $\left(\mathrm{SO}_{2}\right)$ significantly decreased due to the closedown of all industrial and transport activities during lockdown when compared with previous years (Bera et al. 2020). There was also a prominent reduction of surface temperature by $0.23-3.2{ }^{\circ} \mathrm{C}$ within the lockdown ambience in Kolkata.

In Milan (Italy), urban station results demonstrate there was a significant reduction in the levels of PM10, PM2.5, black carbon (BC), benzene, $\mathrm{CO}$ and nitrogen oxides (NOx) during the lockdown. $\mathrm{SO}_{2}$ levels remained unchanged in most peripheral areas, and despite the decrease in $\mathrm{NO}_{2}$ levels, there was an increase in ozone $\left(\mathrm{O}_{3}\right)$ levels, probably due to lower nitrogen monoxide (NO) concentrations (Collivignarelli et al. 2020). In European cities Nice (France), Rome and Turin (Italy), and Valencia (Spain), $\mathrm{NO}_{2}$ concentrations decreased by $\sim 53 \%$ in urban stations and $\sim 65 \%$ in traffic zone stations while nitrogen monoxide concentrations (NO) decreased further, by $\sim 63 \%$ at urban stations and $\sim 78 \%$ at traffic stations, when the isolation period is compared with the same period in the years 2017-2019 (Sicard et al. 2020). The concentration of $\mathrm{PM}_{2.5}$ reduced by 20-60\% in other world cities, such as Bogota (Colombia), Kubait City (Bahrain), Tehran (Iran), Taskhkent (Uzbekistan), Ulaanbaatar (Mongolia), Kabul (Afghanistan), Colombo (Sri Lanka), Almaty (Kazakhstan) and Turkey compared with a period prior to the lockdown or compared with the average figures for the same days in 2018-2019 (Rodríguez-Urrego and Rodríguez-Urrego 2020; Kerimray et al. 2020; Aydin et al. 2020). Salé (Morocco) showed reductions by $75 \%$ for $\mathrm{PM}_{10}, 49 \%$ for $\mathrm{SO}_{2}$, and $96 \%$ for $\mathrm{NO}_{2}$ levels during the lockdown when compared with the previous period (Otmani et al. 2020).

In the state of São Paulo (Brazil), during the initial period of partial lockdown (until April 20th, 2020) drastic reductions were observed in the emissions of NO (up to $77.3 \%$ ) and $\mathrm{NO}_{2}$ (up to $54.3 \%$ ), as well as a reduction in $\mathrm{CO}$ concentrations (up to 
$64.8 \%$ ) compared with the monthly average of previous years. However, an increase of about $30 \%$ was observed in $\mathrm{O}_{3}$ concentrations in urban areas, probably due to reduced car traffic and decreased NO emissions (Nakada and Urban 2020). Krecl et al. (2020) compared the NOx reductions (40-70\%) of this unprecedented event with reductions brought about by the strike organized by truck drives which brought several sectors of Brazil to a halt for 10 days in 2018. In Rio de Janeiro, the second-most populous city in Brazil, measurements of the city's air quality showed significant reductions in $\mathrm{CO}$ levels (between 37.0\% and 43.6\%) and $\mathrm{NO}_{2}$ (between 24.1 and 32.9\%) during the first lockdown month compared with the same period of 2019. Levels of $\mathrm{PM}_{10}$ were only reduced in the first lockdown week (Dantas et al. 2020). In Brazil, there was no consensus about the importance and the need for social distancing, reflected in an increase in urban mobility, even during the pandemic (Dantas et al. 2020).

While the positive impact on air quality may be temporary, this type of reduction can assist governments and individuals to learn how to reduce pollution in the long term, and to foresee alternatives to decrease the use of fossil fuels in the future (Muhammad et al. 2020; Rodríguez-Urrego and Rodríguez-Urrego 2020). Pandemics and calamities have occurred several times throughout human history, leading to-besides numerous deaths - changes in society's habits and urban planning. According to Gouveia and Kanai (2020), the pandemic caused by SARS-CoV-2 once again reveals the relationship between health and the urban environment. Anthropogenic action modifies or destroys biodiversity; this fact, allied to climate change, is possibly directly related to the emergence of new viruses, as is the case of the virus that causes COVID-19 (Lorentzen et al. 2020). Moreover, urban design, climatic and environmental variables, housing configurations, population density, and sanitary and transport infrastructure, may or may not favor the control of a pandemic.

Most recent studies related to the emission of pollutants during the COVID-19 pandemic have evaluated changes in air quality compared with a period prior to the lockdown (Aydin et al. 2020; Bashir et al. 2020; Collivignarelli et al. 2020; Dantas et al. 2020; Mahato et al. 2020; Muhammad et al. 2020; Nakada and Urban 2020; Otmani et al. 2020; Rodríguez-Urrego and Rodríguez-Urrego 2020; Sarkar et al. 2020; Sicard et al. 2020). Some authors sought to correlate other aspects, such as climatic variables and the spread or lethality of COVID-19 (Conticini et al. 2020; Fattorini and Regoli 2020; Guo et al. 2020; Hendryx and Luo 2020; Jahangiri et al. 2020; Kerimray et al. 2020; Ogen 2020; Prata et al. 2020; Rehman et al. 2020; Singh et al. 2020; Qi et al. 2020). The effect of mobility habits in the spread of the Coronavirus in Italy was analyzed by Cartenì et al. (2020) in Italy, while Bao and Zhang (2020) related mobility indices to air quality in the lockdown period in Chinese cities.

This article is distinctive and relevant because it identifies the relationship between the pollutant concentrations during the prolonged lockdown at the time of the COVID-19 pandemic and the reduced movement of people in the city of São Paulo; São Paulo is the largest city in Latin America, moreover, no studies in South America have addressed this type of analysis so far. Furthermore, the main question raised in this study is: "What is the impact on air pollutant emissions in the context of social isolation in a longer term?" With this question in mind, this study aims to detect the relationship between the social isolation index in the megacity of São Paulo and the fluctuation in the levels of the main air pollutants $\left(\mathrm{PM}_{10}, \mathrm{PM}_{2.5}, \mathrm{NO}_{\mathrm{x}}, \mathrm{NO}, \mathrm{NO}_{2}, \mathrm{SO}_{2}\right.$ and $\left.\mathrm{CO}\right)$ and air temperature. This study analyzed the period between March 16th, 2020, and July 20th, 2020, and compared it with the previous period in 2020 and the previous 5 years (2015-2019), based on data from three urban air quality monitoring stations located in the city center of São Paulo. 


\section{Description of the studied area}

São Paulo is the largest urban agglomeration in the Southern Hemisphere, with an area of $7,946 \mathrm{~km}^{2}$, connecting 39 municipalities and a population of 20 million, and it is one of the most populous cities in the world (Krecl et al. 2020; SEADE 2020). São Paulo also has one of the largest vehicle fleets in the country, and a high concentration of industries that have a direct impact on urban air quality in the area. Due to this fact, São Paulo has the worst air pollution indices in the country, with emissions of 132 thousand $t / Y e a r$ of carbon monoxide (CO), 42 thousand $\mathrm{t} /$ Year of hydrocarbons (HC), 77 thousand $\mathrm{t} /$ Year of nitrogen oxides $\left(\mathrm{NO}_{\mathrm{x}}\right), 4.5$ thousand $\mathrm{t} /$ Year of particulate matter $(\mathrm{PM})$ and 11 thousand $\mathrm{t} /$ Year of sulfur oxides $\left(\mathrm{SO}_{\mathrm{x}}\right)$; vehicles are responsible for $97 \%$ of $\mathrm{CO}$ emissions, $81 \% \mathrm{HC}, 80 \% \mathrm{NOx}, 48 \%$ $\mathrm{SO}_{\mathrm{x}}$ and 40\% PM (Gouveia et al. 2017).

The disordered urbanization and increase in the number of sources of air pollution over the years, mainly due to the high concentration of cars and factories, has led to a critical situation with regard to air quality in São Paulo (Andrade et al. 2017). Occupying cities more densely is very effective in terms of economy and the footprint left by carbon dioxide $\left(\mathrm{CO}_{2}\right)$ emissions; however, when high density is the result of a disordered urbanization process, it leads to problems associated with the population's quality of life, especially the poorest strata, which makes urban live unsustainable (Jacobi 2013). Thus, it is noteworthy that in addition to population density, the transmission of COVID-19 can be affected by different factors such as climatic conditions (temperature and humidity) and the quality of the health system (Wang et al. 2020; Jahangiri et al. 2020). Moreover, the high concentration of pollutants in the air may be directly associated with a higher probability of contamination in this pandemic (Zhu et al. 2020; Fattorini and Regoli 2020; Hendryx and Lou 2020; Conticini et al. 2020), while the long-term exposure to nitrogen dioxide $\left(\mathrm{NO}_{2}\right)$ can be one of the factors that most contribute to mortality caused by the Coronavirus (Ogen 2020). On the other hand, paradoxically, the COVID-19 pandemic may have decreased the total number of deaths from air pollution during the lockdown periods (Dutheil et al. 2020).

The first case of COVID-19 in Brazil was confirmed on February 26, 2020. On July 20, 2020, the country counted 2,121,645 cases and 80,251 deaths (Brazil 2020). The city of São Paulo continued to lead the numbers of cases and deaths, which caused the prolongation of the social isolation rules. A municipal decree issued on March 17, 2020, marked the beginning of restrictions while the first actions to ease the partial lockdown were put in practice on June 10, 2020, when some businesses were reopened. July 20, 2020, is the 125 th day of social isolation and reductions in urban mobility, albeit with different restriction levels.

\section{Methods}

\subsection{Environmental variables and pollutants data}

The primary data of the pollutant concentrations $\mathrm{PM}_{10}, \mathrm{PM}_{2.5}, \mathrm{NO}_{\mathrm{x}}, \mathrm{NO}, \mathrm{NO}_{2}, \mathrm{SO}_{2}, \mathrm{CO}$ and the environmental variables (air temperature and relative humidity) were obtained from the regional agency in charge of the air quality monitoring stations in the state Companhia Ambiental do Estado de São Paulo, CETESB (2020). In addition to pollutants related to air quality, we chose to verify air temperature since internal combustion 
engine vehicles are responsible for considerable emissions of anthropogenic heat in urban centers. For this study, three air quality monitoring stations were selected in the Central Region of São Paulo, an urban area characterized by heavy automobile traffic. We prioritized air quality monitoring stations registering the same variables, with $84.4 \%$ of the primary data validated: Marginal Tietê (Station A); Dom Pedro II Bus Terminal (Station B) and Marginal Pinheiros (Station C) (Fig. 1). Station B is setup at a bus terminal, while stations $\mathrm{A}$ and $\mathrm{C}$ are next to heavy traffic expressways.

We collected the primary data of the three stations in the form of hourly averages, and then we calculated daily averages (arithmetic mean of 24-h monitoring values) for each pollutant and environmental variable, from January 1 to July 20, 2020. Adopting daily values for the variables allowed us to compare them with the social isolation indices, as explained in item 2.3, to detect changes in the time series and quantify the effect of social isolation on the emission levels of pollutants, and environmental variables. In the weeks preceding the decree that started social isolation, there was a national holiday, which traditionally implies a reduction in the operation of businesses and, consequently, in mobility in urban centers. For this reason, this study prioritized analyzing the variations of the daily average concentrations compared with the same period of the previous 5 years, from 2015 to 2019. In an initial analysis, a similar behavior was observed in the daily variations at each monitoring station, so the average value of the three monitoring stations was used as a reference in this study.

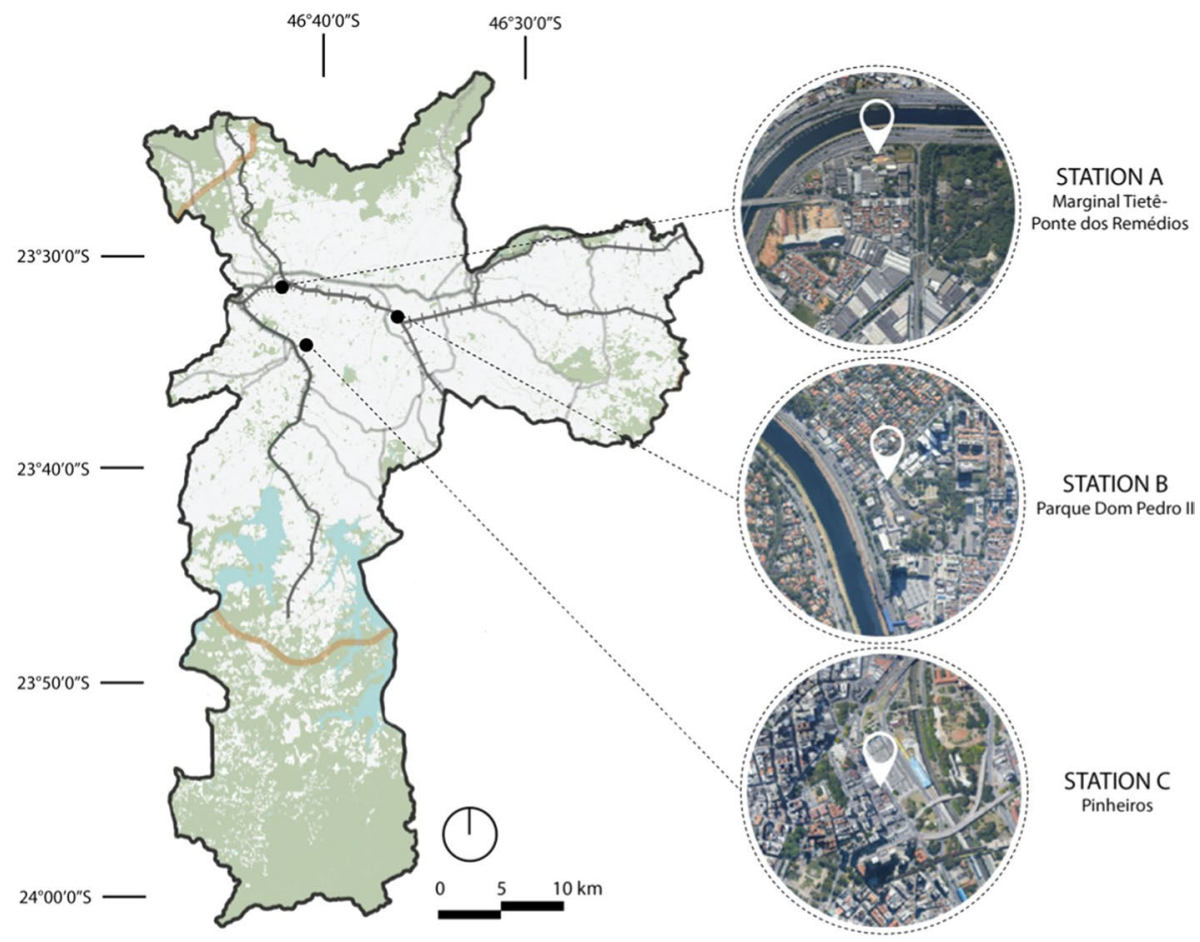

Fig. 1 Location of air quality monitoring stations in the city of São Paulo 


\subsection{Social isolation index}

The decree that reduced urban mobility in São Paulo did not lead to a total stop (lockdown), rather, it was considered partial (partial lockdown) compared with the level of restrictions observed in other cities around the globe. The reduction in population movement was quantified by the "social isolation index" created by the São Paulo State Government, as a yardstick for adopting official measures to fight COVID-19 (São Paulo 2020). Bao and Zhang (2020) indicated human mobility as one potential mechanism to estimate the effects of the implementation of travel restrictions on air pollution. To establish the link between lockdown and air pollution reductions, the authors used a human mobility index measured on mobility records from a Chinese online search engine with a desktop and mobile mapping application. Cartenì et al. (2020) used an average daily mobility rate estimated by an institute for research about mobility and logistics in Italy plus data collected by car traffic count automatic sensors from the "COVID-19 mobility observatory" of the Italian Transport Ministry to quantify the effect of mobility habits in the spread of the Coronavirus in Italy. The two aforementioned studies used different types of local data sources regarding the mobility and movement of people in cities.

To establish the link between urban mobility and air pollution reductions in the period of partial lockdown, we used the official daily numbers of the social isolation index for the city of São Paulo (São Paulo 2020). The monitoring system in São Paulo, where the technical team of the Institute of Technological Research (Instituto de Pesquisas Tecnológicas-IPT) operates, updated the daily index of adherence to social isolation upon analyzing mobile phone data to indicate mobility trends and assess the effectiveness of social isolation measures. The index is based on the location obtained by cell phone antennas (Base Radio Stations), which identify a reference for the place where the cell phone "slept" between 10 p.m. and 2 a.m. During the day, a mobile phone that has moved about $200 \mathrm{~m}$ away from this reference point is accounted for as a device not in isolation. The data are made available by telecommunication service providers present in the state of São Paulo and managed by the Brazilian Association of Telecommunication Resources (Associação Brasileira de Recursos em Telecomunicações) through a Big Data platform (IPT 2020). Because the system locates the telephones in use through their antennas-and not the GPS - their location cannot be hidden.

\subsection{Data analysis}

The collected data were tabulated and analyzed on a Microsoft Excel spreadsheet. Descriptive analysis was performed for all the data, and linear regression analysis and Pearson's correlation were conducted to verify the relationship between social isolation and the emission of pollutants. For statistical analyses, the initial procedure consisted of verifying the normality of all data, by using as criteria the Asymmetry values ranging from +3 to -3 , and Kurtosis values between +8 and -8 , as proposed by Kline (2011) to accept data as normal. Correlation analyses were used in other studies related to the COVID-19 pandemic to identify, for example, the relationship of the number of cases and deaths with environmental variables (Singh et al. 2020; Bashir et al. 2020), and the association among the different pollutants (Sarkar et al. 2020). Linear regression was used by Prata et al. (2020) to identify the relationship of the number of cases with air temperature and population density. 


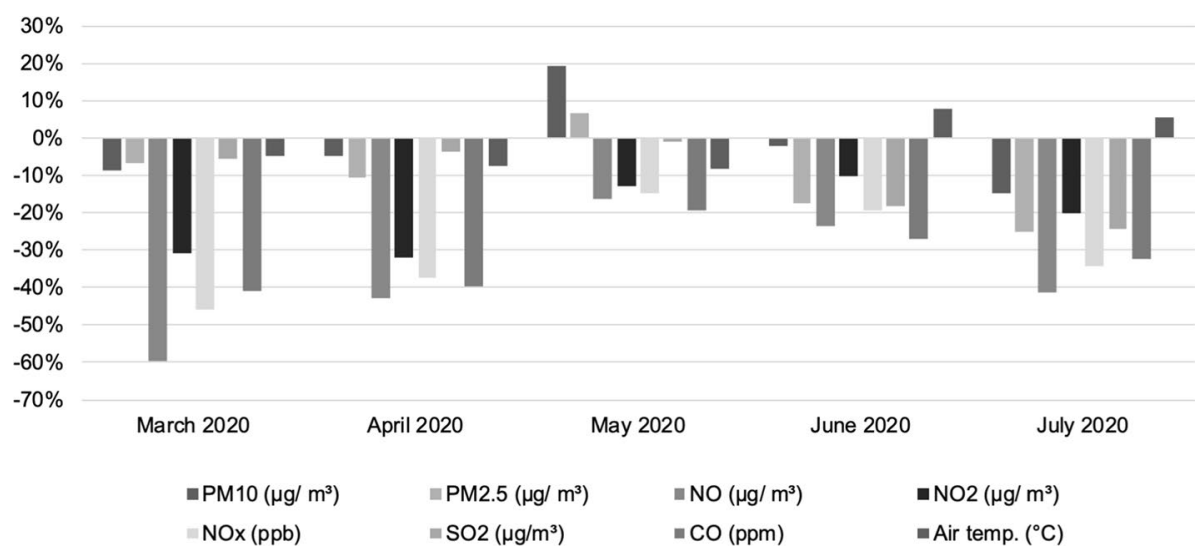

Fig. 2 Pollutant monthly variation (March 17, 2020, to July 20, 2020)

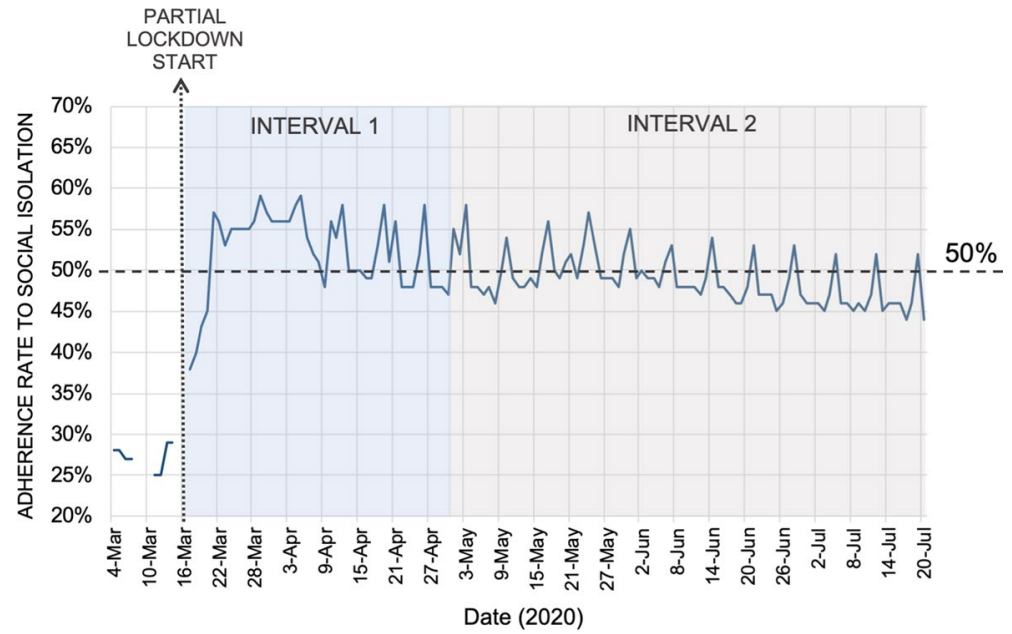

Fig. 3 Social isolation adherence index identified by the São Paulo State Government. Two distinct ranges are identified: interval 1 (from March 17, 2020, to April 30, 2020) and interval 2 (from May 1, 2020)

\section{Results}

The pollutants' daily average values, calculated on the three monitoring stations located in the Central Region of São Paulo, demonstrate a reduction in concentrations in 2020 compared with the average for the same period of the previous 5 years (2015-2019). However, such reduction was more pronounced in the period of social isolation due to the COVID-19 pandemic, especially in the first months after the decree that reduced mobility in the city, for the pollutants $\mathrm{NO}, \mathrm{NO}_{2}$ and $\mathrm{CO}$, as reported by Nakada and Urban (2020), and also $\mathrm{NO}_{\mathrm{x}}$ (Fig. 2).

By superimposing the daily average data for 2020 , the daily average data for the preceding 5 years (2015-2019), and the social isolation index (Figs. 3, 4), we notice a similar behavior in the emissions of all the pollutants during two distinct time periods of the pandemic: the first 45 days (interval 1 -March 17, 2020, to April 30, 2020), when isolation 

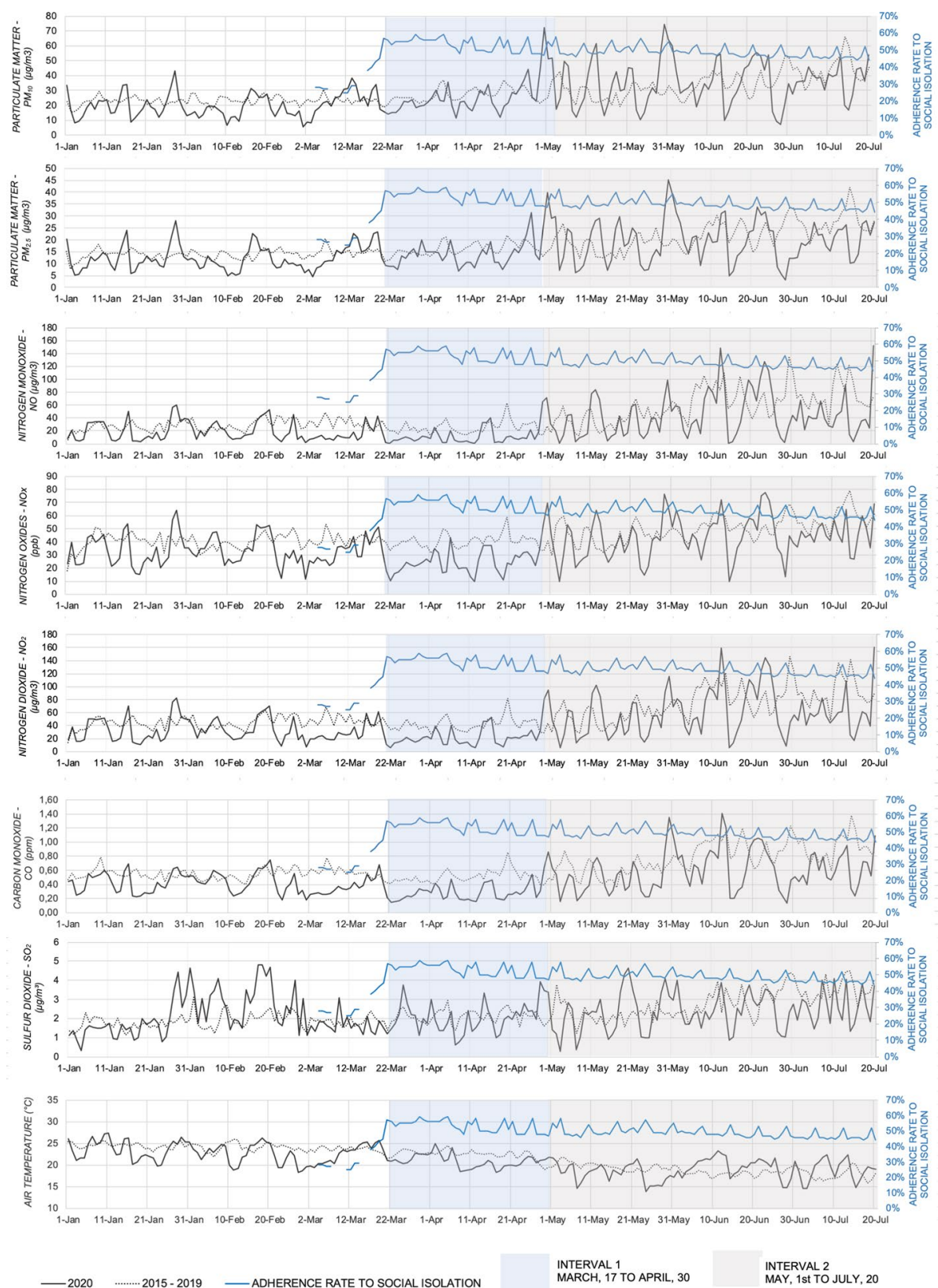

Fig. 4 Average values of pollutants and environmental variables in 2020, 2015-2019 average, and social isolation index

rates were mostly over $50 \%$ (yet below $70 \%$ recommended by the World Health Organization-WHO); and the next few months (interval 2-May 1, 2020, to July 20, 2020), with bigger fluctuations, and averages predominantly below $50 \%$ (Fig. 3). The national holiday on May 1st marks the beginning of interval 2. While the first period of partial lockdown is 
marked by greater reductions in the emission of pollutants, the second period is characterized by greater fluctuations of nearly all pollutants analyzed in this study. In this period, the maximum averages stand out because they reached higher values than those for both the period prior to the partial lockdown and the average of the previous 5 years (Fig. 4). Table 1 and Fig. 5 show the average values for the months of January to July 20, 2020, and for the same period of the previous 5 years and demonstrate significant reductions in the months of March and April 2020 for pollutants NO (59.62\% Mar and 42.65\% Apr); $\mathrm{NO}_{2}$ (30.86\% Mar and 32.21\% Apr); $\mathrm{NO}_{\mathrm{x}}$ (45.84\% Mar and 37.27\% Apr) and $\mathrm{CO}$ (40.81\% Mar and $39.68 \%$ Apr). In May, however, the reduction trend did not stand, and the emission of pollutants $\mathrm{NO}, \mathrm{NO}_{2}, \mathrm{NO}_{\mathrm{x}}$ and $\mathrm{CO}$ reached higher averages than in the immediate period preceding the pandemic (February) and very close averages to those in the same period in the previous 5 years. About the inhalable particulate matter $\mathrm{PM}_{10}$ and fine inhalable particulate matter $\mathrm{PM}_{2.5}$, their reductions in the months of March and April 2020 were lower than in the period preceding the pandemic; in addition, in May they presented higher average levels than in the previous 5 years: $\mathrm{PM}_{10}=+19.39 \%$ and $\mathrm{PM}_{2.5}=+6.79 \%$. In July, reductions reached $14.62 \%$ and $25.24 \%$, respectively (Table 1 ).

In a semi-monthly analysis since the beginning of the pandemic (Table 2 and Fig. 6), the influence of social isolation indices on the fluctuation of pollutants becomes more evident, with the most relevant negative variations in the 2nd half of March/2020 and in the 1st half of April 2020: NO (48.86\% Mar and 50.13\% Apr); $\mathrm{NO}_{2}$ (33.37\% Mar and 37.58\% Apr); $\mathrm{NO}_{\mathrm{x}}$ (40.86\% Mar and 43.29\% Apr) and CO (34.06\% Mar and 44.32\% Apr). The reductions in these pollutants tend to decrease from the 2nd half of April/2020 on. Inhalable particulate matter $\mathrm{PM}_{10}$, and fine inhalable particulate matter $\mathrm{PM}_{2.5}$ reduced slightly in the first 30 days of partial lockdown while they increased as of the 2nd half of April. Reduced concentrations of $\mathrm{PM}_{2.5}$ are observed from the first week of June while reduced concentrations of $\mathrm{PM}_{10}$ are observed from the second week of June (Table 2).

By analyzing the associations between the social isolation index and the concentration of the seven pollutants (Fig. 6 and Table 3), we see negative correlations between the variables, which demonstrates that the restriction measures and the lesser circulation of people influenced the reduction of air pollution. As to the results, the pollutants $\mathrm{NO}, \mathrm{NO}_{2}, \mathrm{NO}_{\mathrm{x}}$ and $\mathrm{CO}$ presented the strongest correlations, which allow us to affirm that social isolation explained $18.81 \% ; 33.9 \% ; 23.24 \%$, and $13.45 \%$, respectively, of the concentrations of these pollutants in the period. These results agree with Bao and Zhang (2020), who found that travel restriction measures taken in 44 cities in China significantly reduced air pollution emissions of $\mathrm{SO}_{2}, \mathrm{PM}_{2.5}, \mathrm{PM}_{10}, \mathrm{NO}_{2}$, and $\mathrm{CO}$ (a decrease by $6.76 \%, 5.93 \%, 13.66 \%$, $24.67 \%$, and $4.58 \%$, respectively).

Human activity in cities is responsible for generating anthropogenic heat, which comes from various sources such as buildings and cars (Gartland 2010). Vehicle traffic decreased considerably during the partial lockdown and positively affected air quality (Nakada and Urban 2020; Krecl et al. 2020). Besides affecting air quality, automotive vehicles are assumed to influence air temperature records, especially in the areas where the monitoring stations of this study are located, that is, next to intense traffic roads. About the temperature, even if there is a natural decrease due to the season (autumn), in the months of April and May reduction scores are $7.45 \%$ and $8.11 \%$ compared with the five previous years. In June and July, the mean air temperature is higher than in previous years: $+7.83 \%$ in June and $+5.50 \%$ in July (Table 1 ). On the other hand, the result of the linear regression between air temperature and social isolation (Fig. 7), and Pearson's correlation (Table 3) demonstrate no relevant association between these variables, and it is not possible to assert that social isolation contributed to the oscillation of air temperature in the period. 


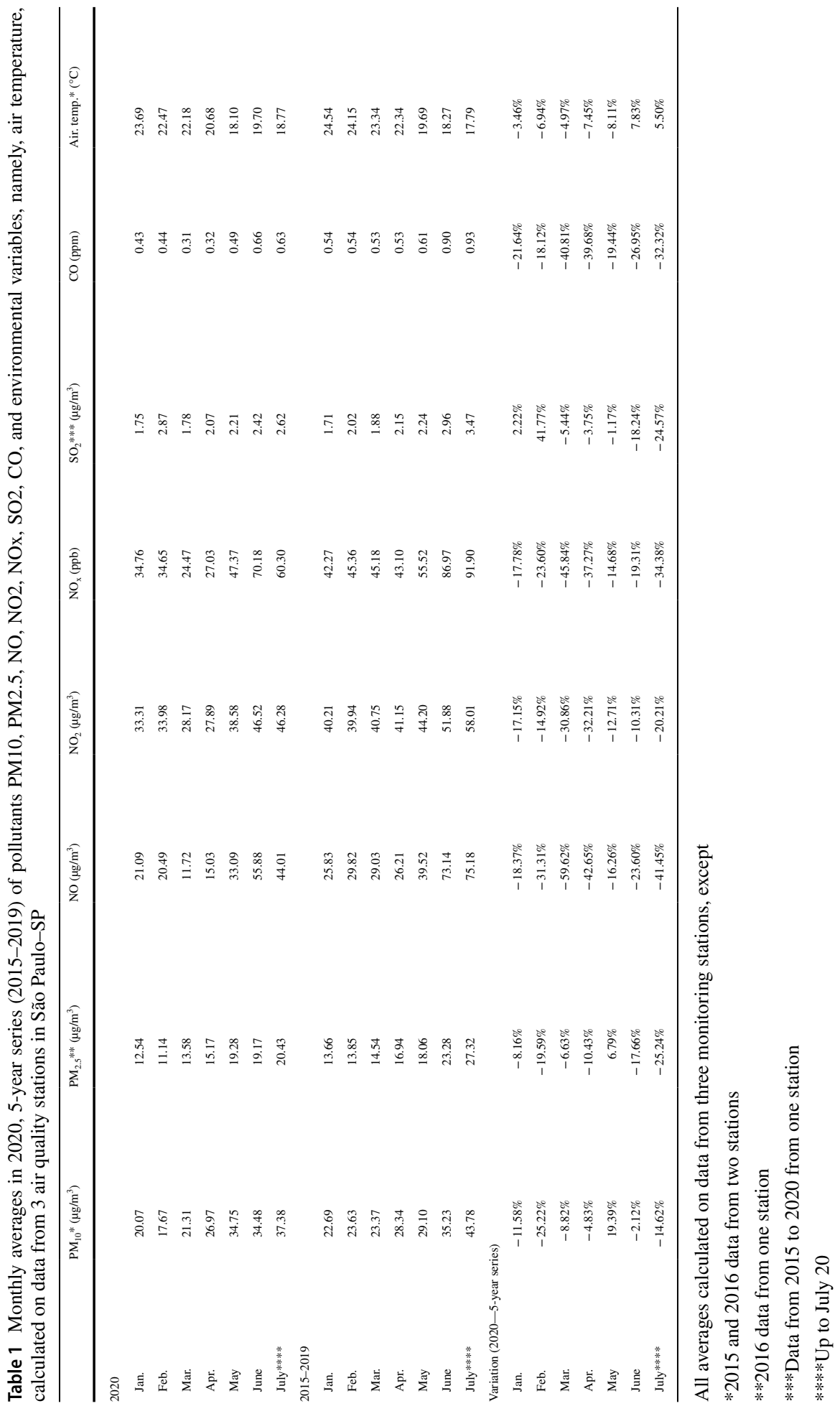




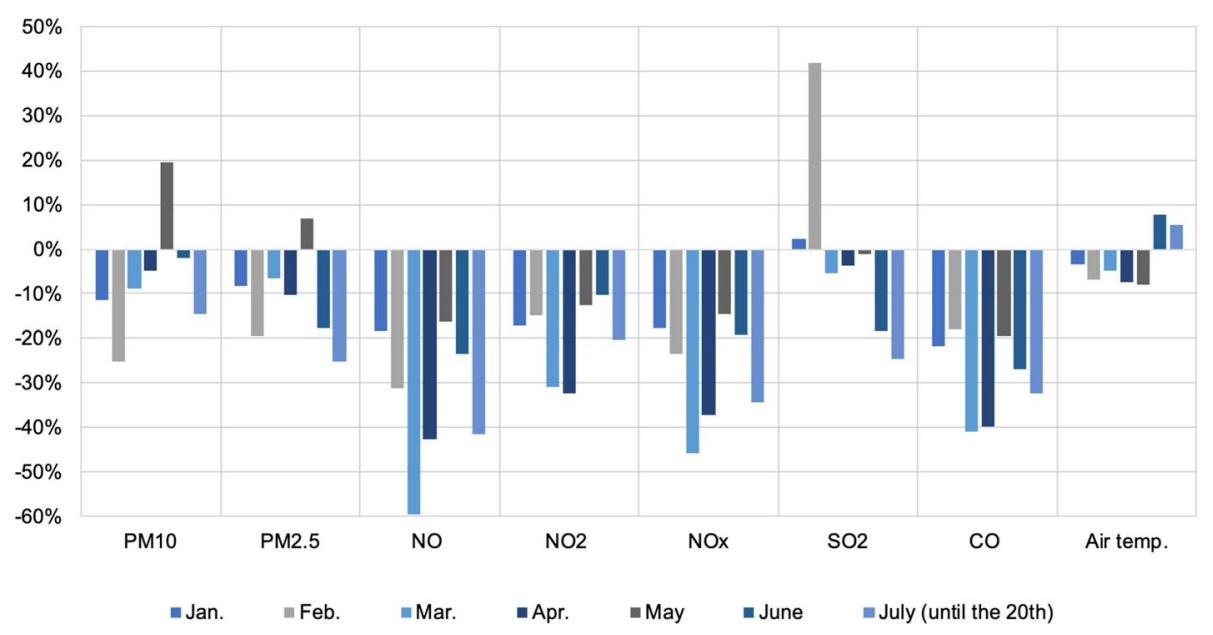

Fig. 5 Pollutant variation (\%) in 2020 compared to the 5-year series (2015-2020), from January to July

\section{Conclusions}

This study concluded that the decrease in urban mobility due to the social isolation imposed by the COVID-19 pandemic had a positive impact on air quality, with a reduction in the emission of pollutants $\mathrm{NO}(31.75 \%), \mathrm{NO}_{2}(20.60 \%), \mathrm{NO}_{\mathrm{x}}(27.21 \%)$ and $\mathrm{CO}$ (29.95\%) considering the partial lockdown period from March 16, 2020, to July 20, 2020. A more notable fall was observed in the initial period of the lockdown, however, when analyzing a longer period (since the lockdown in São Paulo was successively prolonged), from the third month on we noticed a decline in such reductions compared to the beginning of the pandemic. Subtle falls in social isolation rates in the city of São Paulo were reflected in the emission of pollutants in the period.

About the inhalable $\mathrm{PM}_{10}$ and fine inhalable $\mathrm{PM}_{2.5}$ particles, their reductions in the first months of social isolation were lower than in the period immediately before the pandemic; moreover, in May they presented higher average levels than in the previous 5 years: $+19.39 \%$ and $+6.79 \%$, respectively. More relevant reductions were only identified in July (14.62\% and $25.24 \%$ ), which may have been influenced by other aspects not addressed in this study.

From the analyses conducted in this study, we highlight:

- Higher drops in the emission of pollutants $\mathrm{NO}, \mathrm{NO}_{2}, \mathrm{NO}_{\mathrm{x}}$ and $\mathrm{CO}$ were observed when the social isolation index reached an average of $52.20 \%$;

- Small negative fluctuations in the social isolation index broke the reductions observed at the beginning of the lockdown;

- We notice two distinct periods of the partial lockdown in São Paulo-SP, with the predominance of indices above $50 \%$ in the first 45 days (interval 1) and predominance of indices below $50 \%$ in the following period (interval 2).

- The relationships between pollutant concentrations and the social isolation index showed that the decrease in mobility influenced the reduction of air pollution. Pollutants $\mathrm{NO}_{2}, \mathrm{NO}_{\mathrm{x}}, \mathrm{NO}$ and $\mathrm{CO}$ had the strongest negative associations (Pearson's correlation $(\rho)=-0.582 ; 0.481 ;-0.433$ and -0.367 , respectively). 


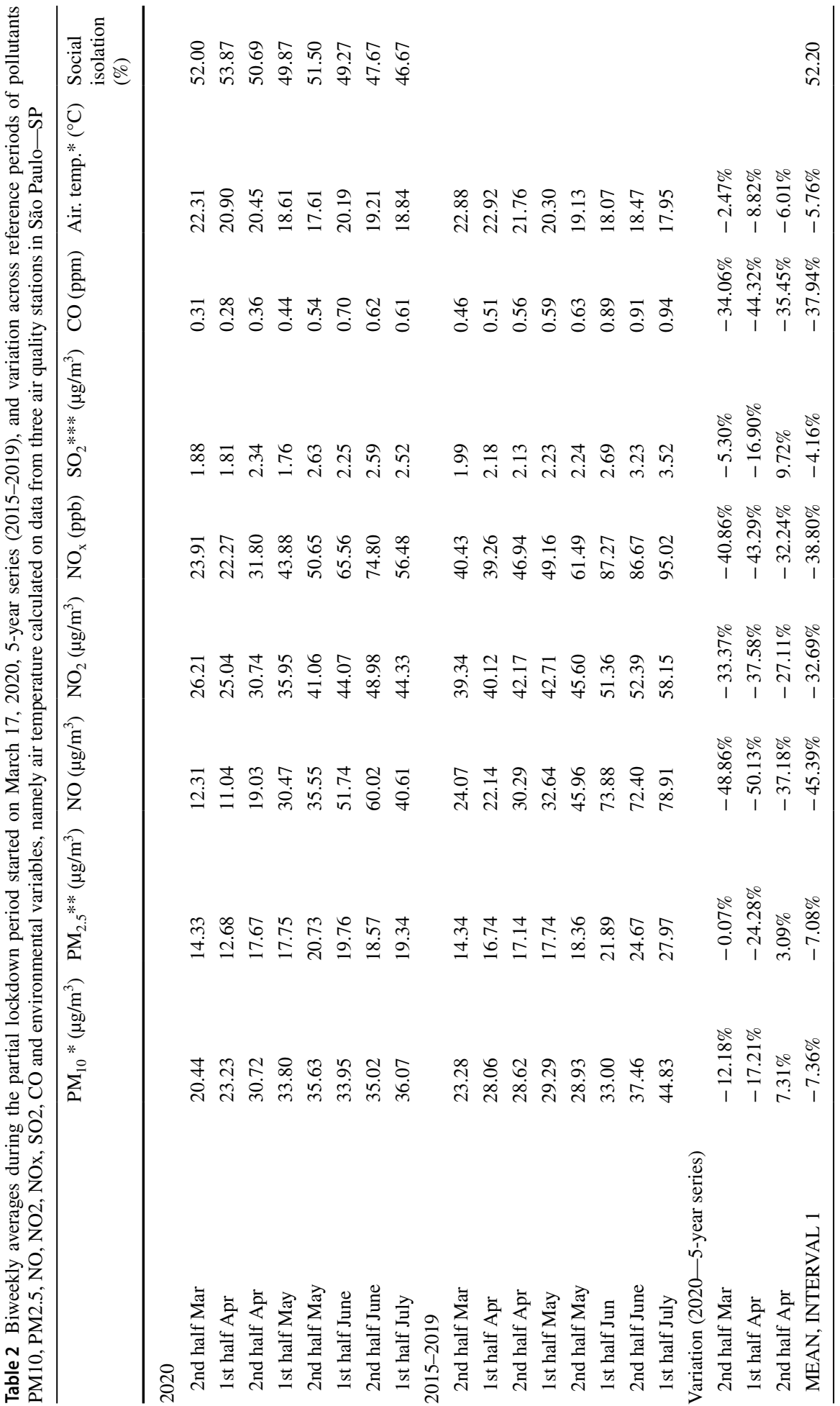




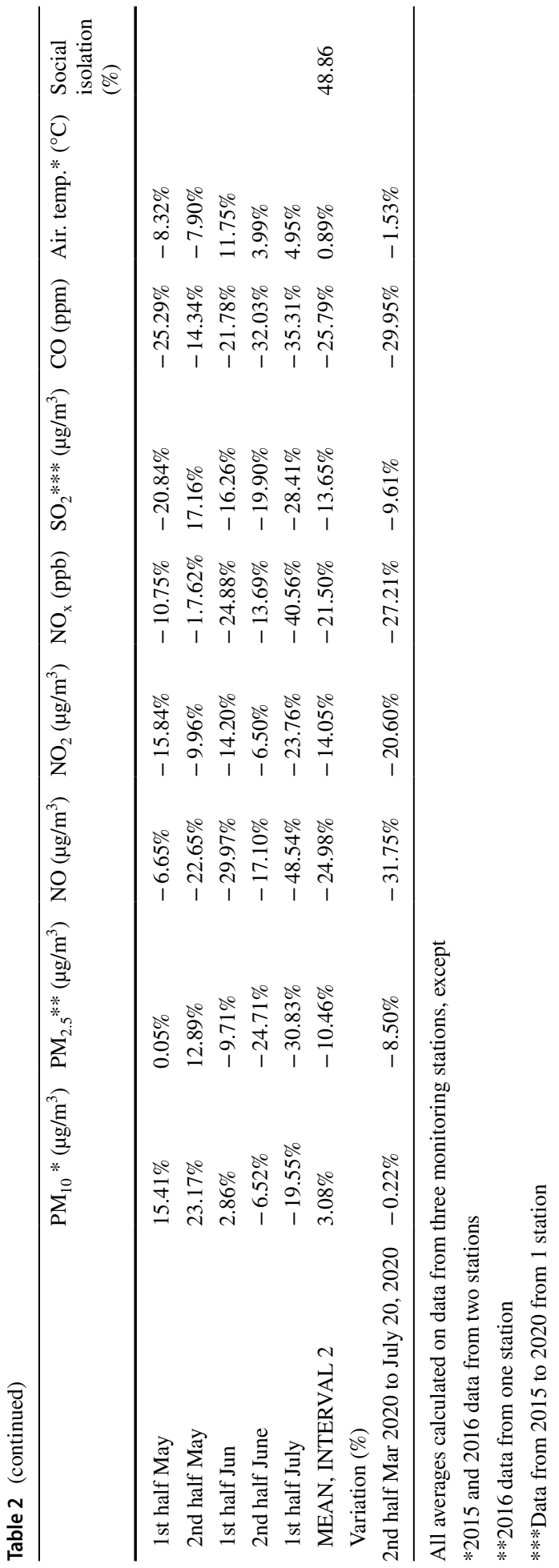




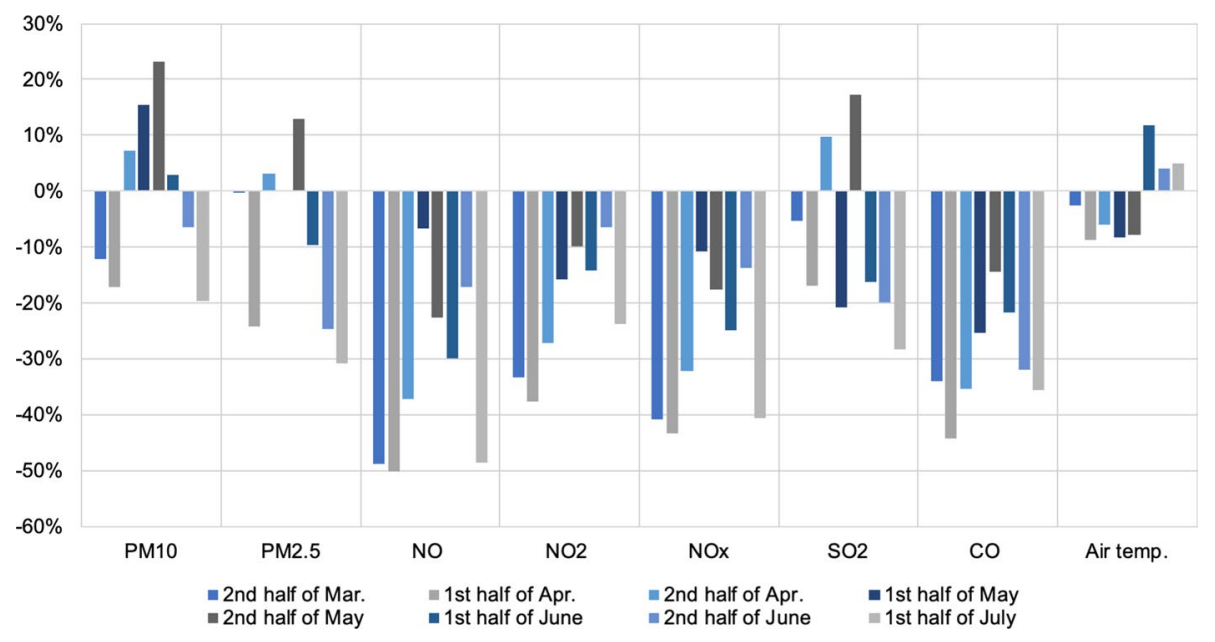

Fig. 6 Pollutant biweekly variation (\%) in 2020 compared to the 5-year series (2015-2020) during the partial lockdown period

Table 3 Pearson's correlation $(\rho)$ and linear regression $\left(R^{2}\right)$ between adherence rate to social isolation with different pollutants and air temperature from March 17 to July 20, 2020, in São Paulo, Brazil

\begin{tabular}{lll}
\hline Variables & Pearson $(\rho)$ & $R^{2}$ \\
\hline $\mathrm{PM}_{10}\left(\mu \mathrm{g} / \mathrm{m}^{3}\right)$ & -0.301 & 0.0909 \\
$\mathrm{PM}_{2.5}\left(\mu \mathrm{g} / \mathrm{m}^{3}\right)$ & -0.223 & 0.0502 \\
$\mathrm{NO}\left(\mu \mathrm{g} / \mathrm{m}^{3}\right)$ & -0.433 & 0.1881 \\
$\mathrm{NO}_{2}\left(\mu \mathrm{g} / \mathrm{m}^{3}\right)$ & -0.582 & 0.339 \\
$\mathrm{NO}_{\mathrm{x}}(\mathrm{ppb})$ & -0.481 & 0.2314 \\
$\mathrm{SO}_{2}\left(\mu \mathrm{g} / \mathrm{m}^{3}\right)$ & -0.304 & 0.0923 \\
$\mathrm{CO}(\mathrm{ppm})$ & -0.367 & 0.1345 \\
Air temperature $\left({ }^{\circ} \mathrm{C}\right)$ & 0.062 & 0.0039 \\
\hline
\end{tabular}

- Other contextual factors may have influenced the fluctuations that occurred for all pollutants in the second period of the partial lockdown, in which maximum values observed are above the last 5 years' average.

This study identified that the reductions of the pollutant levels were not regular in the analyzed period; great oscillations were observed in May and June 2020, which may be the object of further, more in-depth studies. The results herein presented, analyzed on a local scale, demonstrate the potential of a megacity such as São Paulo to reduce the concentrations of air pollutants generated by anthropogenic activities related to urban mobility, even if due to temporary circumstances. As a conclusion, we highlight the importance of understanding the short-term causes, changes and benefits as a path to permanent transformations. 

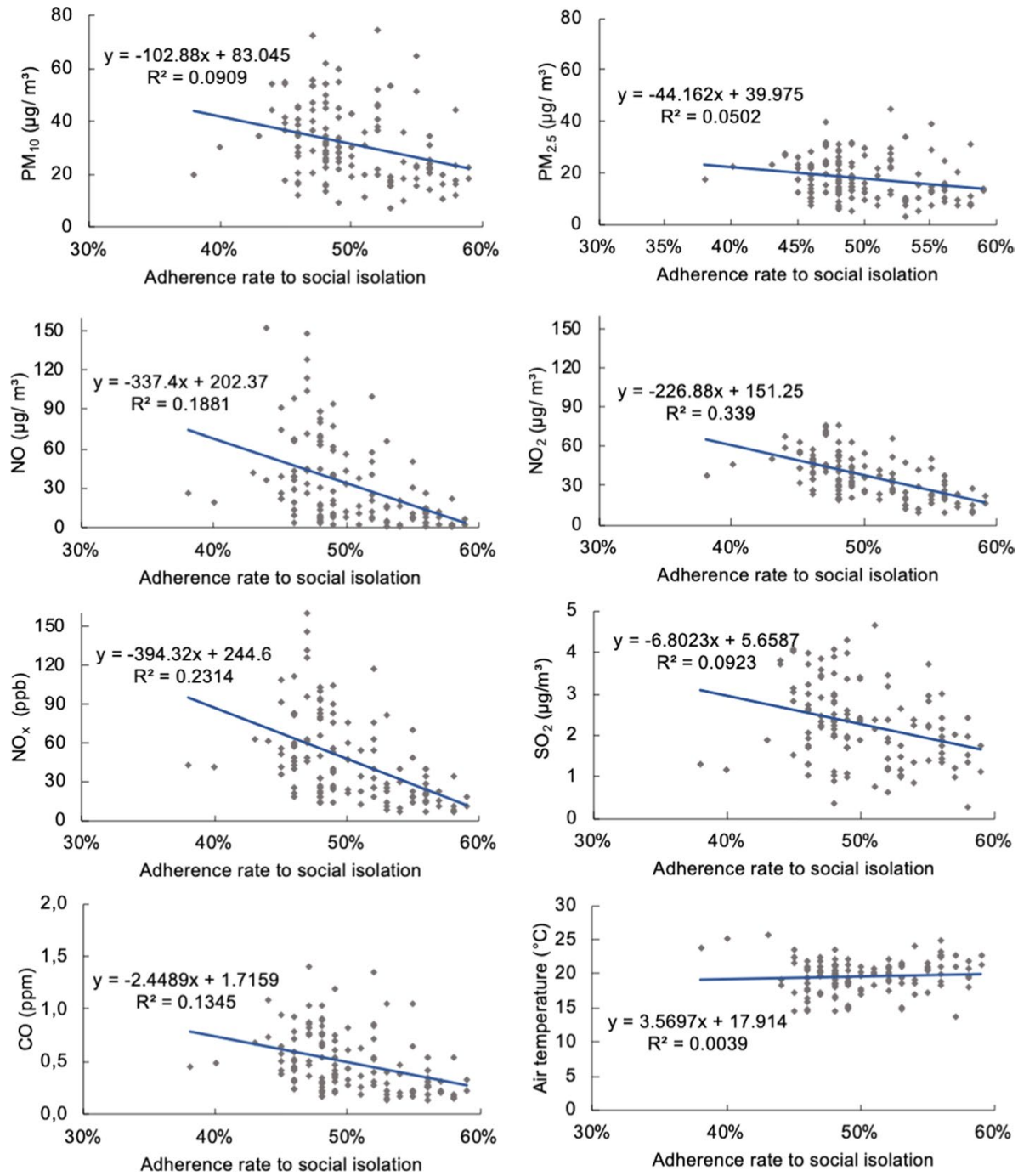

Fig. 7 Relationship of adherence rate to social isolation with different pollutants and air temperature from March 17 to July 20, 2020, in São Paulo, Brazil

\section{Limitations}

- The air quality monitoring system in São Paulo has a wide network of stations, however, they do not record the same variables. For this reason, only three stations that recorded the same variables were chosen for this study, thus allowing the comparison over time.

- There are data gaps, especially $\mathrm{PM}_{10}$ and $\mathrm{PM}_{2.5}$ in 2015 and 2016, and $\mathrm{SO}_{2}$ from 2015 to 2020 . 


\section{Future research directions}

- Since the COVID-19 pandemic is not over; the population has not yet been vaccinated and immunized; and, there are forecasts of new contamination peaks, a longitudinal study is recommended to identify the long-term impact of the reduction of urban anthropogenic activities due to the pandemic.

- Other contextual factors can be investigated to identify the oscillations and peaks in the emission of pollutants in the second partial lockdown period (from May to June 2020).

- Other sources of data on mobility during the pandemic, such as the Google Community Mobility Report, may contribute to better understand the impact of a partial lockdown on urban activities.

Acknowledgements We acknowledge CETESB (Companhia Ambiental do Estado de São Paulo) for providing the air pollution and meteorological data through the QUALAR database (https://cetesb.sp.gov.br/ar/ qualar/).

Authors' contributions LN participated in the conceptualization, supervision, methodology, investigation, formal analysis, writing of the original draft and writing of the review and editing; ABEQN involved in supervision, methodology, writing of the original draft and writing of review and editing; JBMSJ participated in writing of the original draft and visualization; FS involved in data curation and formal analysis; LL participated in the conceptualization, writing of the review and editing.

Funding This research did not receive any specific grant from funding agencies in the public, commercial or not-for-profit sectors.

\section{Compliance with ethical standards}

Conflicts of interest The authors declare that they have no conflict of interest.

\section{References}

Andrade, M. F., et al. (2017). Air quality in the megacity of São Paulo: Evolution over the last 30 years and future perspectives. Atmospheric Environment, 159, 66-82. https://doi.org/10.1016/j.atmos env.2017.03.051.

Aydin, S., et al. (2020). Environmental impact of coronavirus (COVID-19) from Turkish perceptive. Environment, Development and Sustainability. https://doi.org/10.1007/s10668-020-00933-5.

Bao, R., \& Zhang, A. (2020). Does lockdown reduce air pollution? Evidence from 44 cities in northern China. Science of the Total Environment, 731, 139052. https://doi.org/10.1016/j.scitotenv.2020.13905 2.

Bashir, M. F., Ma, B., Bilal, D., Komal, B., Bashir, M. A., Tan, D., et al. (2020). Correlation between climate indicators and COVID-19 pandemic in New York, USA. Science of the Total Environment, 728, 138835. https://doi.org/10.1016/j.scitotenv.2020.138835.

Bera, B., Bhattacharjee, S., Shit, P. K., Sengupta, N., \& Saha, S. (2020). Significant impacts of COVID-19 lockdown on urban air pollution in Kolkata (India) and amelioration of environmental health. Environment, Development and Sustainability. https://doi.org/10.1007/s10668-020-00898-5.

Brazil (2020). Ministry of Health-COVID19—Coronavirus Panel. https://covid.saude.gov.br/. Accessed 25 July 2020.

Cartenì, A., Di Francesco, L., \& Martino, M. (2020). How mobility habits influenced the spread of the COVID-19 pandemic: Results from the Italian case study. Science of the Total Environment, 741, 140489. https://doi.org/10.1016/j.scitotenv.2020.140489.

CETESB-Companhia Ambiental do Estado de São Paulo. (2020). QUALAR: Qualidade do ar, São Paulo. https://cetesb.sp.gov.br/ar/qualar. Accessed 21 July 2020. 
Collivignarelli, M. C., Abbà, A., Bertanza, G., Pedrazzani, R., Ricciardi, P., \& Carnevale Miino, M. (2020). Lockdown for CoViD-2019 in Milan: What are the effects on air quality? Science of the Total Environment, 732, 139280. https://doi.org/10.1016/j.scitotenv.2020.139280.

Conticini, E., Frediani, B., \& Caro, D. (2020). Can atmospheric pollution be considered a co-factor in extremely high level of SARS-CoV-2 lethality in Northern Italy? Environmental Pollution, 261, 114465. https://doi.org/10.1016/j.envpol.2020.114465.

Dantas, G., Siciliano, B., França, B. B., Silva, C. M., \& Arbilla, G. (2020). The impact of COVID-19 partial lockdown on the air quality of the city of Rio de Janeiro, Brazil. Science of the Total Environment, 729, 139085. https://doi.org/10.1016/j.scitotenv.2020.139085.

Dutheil, F., Baker, J. S., \& Navel, V. (2020). COVID-19 as a factor influencing air pollution? Environmental Pollution, 263, 2019-2021. https://doi.org/10.1016/j.envpol.2020.114466.

EESA - The European Space Agency (2020 a). COVID-19: nitrogen dioxide over China. EESA-The European Space Agency. https://www.esa.int/Applications/Observing_the_Earth/Copernicus/Senti nel-5P/COVID-19_nitrogen_dioxide_over_China. Accessed 25 April 2020.

EESA-The European Space Agency (2020b). Air pollution drops in India following lockdown. https ://www.esa.int/Applications/Observing_the_Earth/Copernicus/Sentinel-5P/Air_pollution_drops in_India_following_lockdown. Accessed 25 April 2020.

EESA-The European Space Agency (2020c). Air pollution remains low as Europeans stay at home. https://www.esa.int/Applications/Observing_the_Earth/Copernicus/Sentinel-5P/Air_pollution_ remains_low_as_Europeans_stay_at_home. Accessed 25 April 2020.

Fattorini, D., \& Regoli, F. (2020). Role of the chronic air pollution levels in the Covid-19 outbreak risk in Italy. Environmental Pollution, 264, 114732. https://doi.org/10.1016/j.envpol.2020.114732.

Gartland, L. (2010). Ilhas de Calor: Como mitigar zonas de calor em áreas urbanas. São Paulo: Oficina de Textos.

Gouveia, N., Corrallo, F. P., Ponce de Leon, A. C., Junger, W., \& Freitas, C. U. (2017). Poluição do ar e hospitalizações na maior metrópole brasileira. Revista de Saude Publica, 51, 117. https://doi. org/10.11606/S1518-8787.2017051000223.

Gouveia, N., \& Kanai, C. (2020). Pandemics, cities and public health. Ambiente e Sociedade, 23, 1-12. https://doi.org/10.1590/1809-4422ASOC20200120VU2020L3ID.

Guo, X. J., Zhang, H., \& Zeng, Y. P. (2020). Transmissibility of COVID-19 in 11 major cities in China and its association with temperature and humidity in Beijing, Shanghai, Guangzhou, and Chengdu. Infectious Diseases of Poverty, 9, 1-13. https://doi.org/10.1186/s40249-020-00708-0.

Hendryx, M., \& Luo, J. (2020). COVID-19 prevalence and fatality rates in association with air pollution emission concentrations and emission sources. Environmental Pollution, 265, 115126. https://doi. org/10.1016/j.envpol.2020.115126.

Instituto de Pesquisas Tecnológicas-IPT. Notícias: Perguntas sobre isolamento social. https://www.ipt. br/noticia/1623_perguntas_sobre_isolamento_social.htm. Accessed 19 June 2020.

Jacobi, P. R. (2013). São Paulo metrópole insustentável-como superar esta realidade? Cad Metrópole, $15,219-239$.

Jahangiri, M., Jahangiri, M., \& Najafgholipour, M. (2020). The sensitivity and specificity analyses of ambient temperature and population size on the transmission rate of the novel coronavirus (COVID-19) in different provinces of Iran. Science of the Total Environment, 728, 138872. https:// doi.org/10.1016/j.scitotenv.2020.138872.

Kerimray, A., et al. (2020). Assessing air quality changes in large cities during COVID-19 lockdowns: The impacts of traffic-free urban conditions in Almaty, Kazakhstan. Science of the Total Environment, 730, 139179. https://doi.org/10.1016/j.scitotenv.2020.139179.

Kline, Rex B. (2011). Principles and practice of structural equation modeling (3rd ed.). New York: The Guilford Press.

Krecl, P., Targino, A. C., Oukawa, G. Y., \& Cassino Junior, R. P. (2020). Drop in urban air pollution from COVID-19 pandemic: Policy implications for the megacity of São Paulo. Environmental Pollution, 265, 19-21. https://doi.org/10.1016/j.envpol.2020.114883.

Layne, S. P., Hyman, J. M., Morens, D. M., \& Taubenberger, J. K. (2020). New coronavirus outbreak: Framing questions for pandemic prevention. Science Translational Medicine. https://doi. org/10.1126/scitranslmed.abb1469.

Lorentzen, H. F., Benfield, T., Stisen, S., \& Rahbek, C. (2020). Covid-19 is possibly a consequence of the anthropogenic biodiversity crisis and climate changes. Danish Medical Journal, 67, A205025.

Mahato, S., Pal, S., \& Ghosh, K. G. (2020). Effect of lockdown amid COVID-19 pandemic on air quality of the megacity Delhi, India. Science of the Total Environment, 730, 139086. https://doi. org/10.1016/j.scitotenv.2020.139086. 
Muhammad, S., Long, X., \& Salman, M. (2020). COVID-19 pandemic and environmental pollution: A blessing in disguise? Science of the Total Environment, 728, 138820. https://doi.org/10.1016/j.scito tenv.2020.138820.

Nakada, L. Y. K., \& Urban, R. C. (2020). COVID-19 pandemic: Impacts on the air quality during the partial lockdown in São Paulo state, Brazil. Science of the Total Environment, 730, 139087. https://doi. org/10.1016/j.scitotenv.2020.139087.

Ogen, Y. (2020). Assessing nitrogen dioxide (NO2) levels as a contributing factor to coronavirus (COVID-19) fatality. Science of the Total Environment, 726, 138605. https://doi.org/10.1016/j.scito tenv.2020.138605.

Otmani, A., et al. (2020). Impact of Covid-19 lockdown on PM10, SO2 and NO2 concentrations in Salé City (Morocco). Science of the Total Environment, 735, 139541. https://doi.org/10.1016/j.scito tenv.2020.139541.

Prata, D. N., Rodrigues, W., \& Bermejo, P. H. (2020). Temperature significantly changes COVID-19 transmission in (sub) tropical cities of Brazil. Science of the Total Environment, 729, 138862. https://doi. org/10.1016/j.scitotenv.2020.138862.

Qi, H., Xiao, S., Shi, R., Ward, M. P., Chen, Y., Tu, W., et al. (2020). COVID-19 transmission in Mainland China is associated with temperature and humidity: A time-series analysis. Science of the Total Environment, 728, 138778. https://doi.org/10.1016/j.scitotenv.2020.138778.

Rehman, A., Ashraf, F., Javed, Z., Hussain, M., Farooq, T. H., Shakoor, A., et al. (2020). The nexus between meteorological parameters and COVID-19 pandemic: Case of Islamabad. Pakistan: Environ. Sustain. https://doi.org/10.1007/s42398-020-00125-X.

Rodríguez-Urrego, D., \& Rodríguez-Urrego, L. (2020). Air quality during the COVID-19: PM2.5 analysis in the 50 most polluted capital cities in the world. Environmental Pollution, 266, 115042. https://doi. org/10.1016/j.envpol.2020.115042.

SÃO PAULO. Adesão ao isolamento social em SP, São Paulo. (2020). https://www.saopaulo.sp.gov.br/ coronavirus/isolamento/. Accessed 11 June 2020.

Sarkar, M., Das, A., \& Mukhopadhyay, S. (2020). Assessing the immediate impact of COVID-19 lockdown on the air quality of Kolkata and Howrah. West Bengal: Envirom. Dev. Sustain. https://doi. org/10.1007/s10668-020-00985-7.

SEADE_Fundação Sistema Estadual de Análise de Dados. (2020). Projeção da população por faixas etárias quinquenais. https://produtos.seade.gov.br/produtos/projpop/index.php. Accessed 1 July 2020.

Shehzad, K., Sarfraz, M., \& Meran Shah, S. G. (2020). The impact of COVID-19 as a necessary evil on air pollution in India during the lockdown. Environmental Pollution, 266, 115080. https://doi. org/10.1016/j.envpol.2020.115080.

Sicard, P., et al. (2020). Amplified ozone pollution in cities during the COVID-19 lockdown. Science of the Total Environment, 735, 139542. https://doi.org/10.1016/j.scitotenv.2020.139542.

Singh, O., Bhardwaj, P., \& Kumar, D. (2020). Association between climatic variables and COVID-19 pandemic in National Capital Territory of Delhi, India. Environment, Development and Sustainability. https://doi.org/10.1007/s10668-020-01003-6.

Tian, H., et al. (2020). An investigation of transmission control measures during the first 50 days of the COVID-19 epidemic in China. Science. https://doi.org/10.1126/science.abb6105.

Wang, J. et al. (2020). High Temperature and high humidity reduce the transmission of COVID-19 (Available SSRN 3551767), https://doi.org/10.2139/ssrn.3551767

Wilder-Smith, A., \& Freedman, D. O. (2020). Isolation, quarantine, social distancing and community containment: pivotal role for old-style public health measures in the novel coronavirus (2019-nCoV) outbreak. Journal of Travel Medicine. https://doi.org/10.1093/jtm/taaa020.

Yang, Y., et al. (2020). The deadly coronaviruses: The 2003 SARS pandemic and the 2020 novel coronavirus epidemic in China. Journal of Autoimmunity, 109, 102434. https://doi.org/10.1016/j.jaut.2020.102434.

Zhu, Y., Xie, J., Huang, F., \& Cao, L. (2020). Association between short-term exposure to air pollution and COVID-19 infection: Evidence from China. Science of the Total Environment, 727, 138704. https:// doi.org/10.1016/j.scitotenv.2020.138704.

Publisher's Note Springer Nature remains neutral with regard to jurisdictional claims in published maps and institutional affiliations. 